\title{
SISTEM PENGAMBILAN KEPUTUSAN PEMILIHAN BIBIT IKAN AIR TAWAR UNTUK DI BUDIDAYAKAN MENGGUNAKAN METODE AHP BERBASIS WEB
}

\author{
Mila Jumarlis \\ Prodi Komunikasi dan Penyiaran Islam STAIN Majene \\ Email : milajumarlis.mirfan@yahoo.com
}

\begin{abstract}
ABSTRAK
Petani budidaya ikan dalam rangka pemilihan bibit ikan yang cocok di budidayakan belum terlalu memperhatikan kondisi geografis dan kualitas air ,Tujuan dari penelitian ini adalah untuk membantu para petani budidaya ikan air tawar dalam memilih jenis bibit ikan yang akan di budidayakan yang sesuai dengan kondisi geografis dan kualitas air di daerah tersebut., Metode yang di gunakan adalah metode AHP, dimana metode AHP adalah sebuah hierarki fungsional dengan input utamanya persepsi manusia. Dengan hierarki, suatu masalah kompleks dan tidak terstruktur dipecahkan ke dalam kelompok-kelompok tersebut diatur menjadi suatu bentuk hierarki. Desain penelitian yang digunakan adalah UML(Unified Modeling Language), yang didesain secara terstruktur yang terdiri dari rancangan model usecase diagram, activity diagram, sequence diagram dan class diagram. Bahasa yang digunakan dalam membangun sistem ini adalah bahasa pemrograman PHP dengan editor sublime text serta menggunakan database xampp, Hasil dari penelitian ini adalah sebuah Sistem Pengambilan Keputusan Pemilihan Bibit Ikan Air Tawar yang dapat memudahkan petani untuk mengambil keputusan dalam pemilihan bibit ikan yang akan dibudidayakan.
\end{abstract}

Kata Kunci: AHP, Bibit, Ikan, Pemilihan, Budidaya.

\begin{abstract}
Farmers in fish farming in the context of selecting suitable fish seeds for cultivation have not paid too much attention to geographical conditions and water quality. The purpose of this study is to assist freshwater fish farming farmers in selecting the types of fish seeds to be cultivated in accordance with geographical conditions and quality. water in the area. The method used is the AHP method, where the AHP method is a functional hierarchy with the main input being human perception. With a hierarchy, a complex and unstructured problem is solved into groups arranged into a hierarchical form. The research design used is UML (Unified Modeling Language), which is designed in a structured manner consisting of usecase diagrams, activity diagrams, sequence diagrams and class diagrams. The language used in building this system is the PHP programming language with a sublime text editor and using the xampp database. The results of this study are a Freshwater Fish Seed Selection Decision Making System that can make it easier for farmers to make decisions in selecting fish seeds.
\end{abstract}

Keywords: AHP, Seeds, Fish, Selection, Cultivation.

\section{PENDAHULUAN}

Produksi perikanan air tawar didominasi oleh ikan Mas, Mujair, Nila, Lele, Patin dan Gurame. Jenis-jenis tersebut menyumbang lebih dari $80 \%$ dari total produksi sisanya adalah budidaya tambak air payau, budidaya di laut, karamba dan jaring apung. Tetapi karena perbed ${ }^{m \infty}$ 
permintaan yang berubah-ubah maka petani budidaya ikan air tawar harus selalu mempertimbangkan budidaya ikan yang menguntungkan untuk dibudidayakan.Ada beberapa hal yang perlu dipertimbangkan dalam rangka pemilihan budidaya ikan air tawar yaitu parameter kondisi air tempat budidaya dan faktor analisis finansial. Untuk kesesuaian air, petani budidaya ikan harus mengukur kondisi air tempat budidaya, dan untuk analisis finansial adalah data biaya yang dikeluarkan dan penerimaan dalam melakukan usaha. Analisis Finansial dipergunakan karena faktor-faktor penilaian investasi dalam analisis finansial bisa memberikan pertimbangan yang dibutuhkan dalam usaha budidaya oleh petani ikan seperti untung-rugi, lama proses pengembalian modal, dan usaha yang masih tetap aman untuk dilakukan walaupun tidak menguntungkan. Semuaya dipadukan untuk mendapatkan penilaian yang bisa membantu proses pengambilan keputusan (Lumentut \& Hartati, 2015)

Petani budidaya ikan sekarang, dalam rangka pemilihan jenis ikan yang cocok di budidayakan yaitu belum terlalu memperhatikan kondisi geografis dan kualitas air di daerah tersebut. Merakapun hanya membtuhkan lokasi dan suplai air yang lancar dan merekapun sudah bisa budidaya bebrapa jenis ikan, tanpa mempertimbangkan bahwa kondisi geografis dan kualitas air di daerah tersebut cocok atau tidak untuk di jadika lokasi budidaya ikan . Dari hal tersebut dapat menyebabkan pertumbuhan ikan menjadi kurang optimal sehingga keuntungan yang di dapat oleh petani tersebut kurang maksimal. Di Indonesia kurang lebih ada 27 jenis ikan air tawar yang bisa di budidayakan, dari 27 jenis ikan air tawar tersebut masing-masing memiliki kriteria lokasi tertenu. Misalnya dalam budidaya ikan mujair harus berada di ketinggian 150$1000 \mathrm{M}$ dari permukaan laut, kualitas air harus jernih, tidak tercenar bahan-bahan kimia beracun, keasaman air yang baik sekitar 7-8 dan suhu air yang baik sekitar 20-250 C. Jika lokasi budidaya ikan mujair tidak sesuai criteria tersebut maka pertumbuhan ikan mujair kurang maksimal (Kosasi, Kuway, Ayu, \& Yuliani, 2015)

\section{LANDASAN TEORI}

2.1 Sistem Pendukung Keputusan

Sistem Pendukung Keputusan (SPK) atau Decision Support System (DSS) adalah sebuah sistem yang mampu memberikan kemampuan pemecahan masalah maupun kemampuan pengkomunikasian untuk masalah dengan kondisi semi terstruktur dan tak terstruktur.Sistem ini digunakan untuk membantu pengambilan keputusan dalam situasi semi terstruktur dan situasi yang tidak terstruktur, dimana tak seorangpun tahu secara pasti bagaimana keputusan seharusnya dibuat (Jumarlis, 2020)

\subsection{Metode AHP}

Metode Analytical Hierarchy Process (AHP) merupakan metode yang banyak digunakan dalam kasus pembobotan kriteria dan penentuan prioritas setiap kriteria berdasarkan matriks perbandingan berpasangan (Rosiska, 2018)

\subsection{Bibit Ikan}

Bibit ikan adalah anak ikan dengan ukuran tertentu yang akan digunakan sebagai bahan organik dalam kegiatan pembudidayaan ikan(Nugroho, Pambudi, Chilmawati, \& Condro, 2012)

\subsection{Ikan Air Tawar}

Ikan air tawar merupakan jenis ikan yang hidup dan menghuni perairan daratan (inland water), 
yaitu perairan dengan kadar garam (salinitas) kurang dari 5 per mil (0-5\%0). Menurut Kartamihardja, et.al. (2007) luas perairan daratan di Indonesia mencapai 54 juta ha. Angka tersebut mencakup perairan umum daratan dengan luas sekitar 13,85 juta ha (terdiri dari sungai dan paparan banjir seluas 12 juta ha,danau seluas 1,80 juta ha, dan waduk seluas 0,05 juta ha); rawa payau dan hutan bakau seluas 39,5 juta ha dan perairan budi daya seluas 0,65 juta ha (mencakupkolam,sawah,dan tambak).

Dari sekitar 2.000 species ikan air tawar yang terdapat di Indonesia, sedikitnya ada 27 jenis yang sudah dibudidayakan. Ikan-ikan yang dibudidayakan tersebut merupakan jenis ikan konsumsi yang memiliki nilai ekonomis penting. Ikan ekonomis penting mengandung arti bahwa ikan-ikan tersebut merupakan jenis ikan yang memiliki nilai ekonomis tinggi untuk diperdagangkan dan dibudidayakan di tanah air (Wargasasmita, Biologi, Pusat, Biodiversitas, \& Fmipa-Ui, 2002)

\section{METODE PENELITIAN}

\subsection{Pengumpulan data}

Data yang telah dikumpulkan adalah jenis Ikan air tawar dari Balai Benih Ikan (BBI) Bontomanai Kabupaten Gowa. Data jenis ikan air tawar diolah menggunakan algoritma AHP dengan Jumlah jenis ikan ada 5 (lima) yaitu Ikan Nila, Ikan Gabus, Ikan Mas, Ikan Patin, dan ikan Gurame. Adapun jumlah bibit ikan yang digunakan untuk ujicoba berjumlah 50 bibit.

\subsection{Algoritma AHP}

AHP (Analytic Hierarchy Process) adalah suatu teori umum tentang pengukuran yang digunakan untuk menemukan skala rasio, baik dari perbandingan berpasangan yang diskrit maupun kontinyu. AHP menguraikan masalah multi faktor atau multi kriteria yang kompleks menjadi suatu hirarki.

\subsection{Lokasi Dan waktu Penelitian}

Penelitian ini dilaksanakan di Balai Benih Ikan Bontomanai Kab Gowa selama 6 bulan di mulai dari maret 2020 sampai dengan September 2020.

\section{HASIL DAN PEMBAHASAN}

4.1 Perhitungan Manual

Dalam tabel perbandingan setiap kriteria akan dibandingkan dengan semua kriteria (termasuk kriteria itu sendiri). Perbandingan nilai antar kriteria yang sama harus 1.

Tabel 4.1 Tabel Matriks Perbandingan Kriteria

\begin{tabular}{|l|l|l|l|l|l|}
\hline Kriteria & $\begin{array}{l}\text { Kualitas } \\
\text { Air }\end{array}$ & $\begin{array}{l}\text { Kadar } \\
\text { Air }\end{array}$ & $\begin{array}{l}\text { Suhu } \\
\text { Air }\end{array}$ & $\begin{array}{l}\text { Jenis } \\
\text { Tanah }\end{array}$ & $\begin{array}{l}\text { Ketinggian } \\
\text { Lokasi dan } \\
\text { air laut }\end{array}$ \\
\hline $\begin{array}{l}\text { Kualitas } \\
\text { Air }\end{array}$ & 1 & 3 & 5 & 9 & 9 \\
\hline Kadar Air & 0.33333 & 1 & 5 & 7 & 9 \\
\hline Suhu Air & 0.2 & 0.2 & 1 & 5 & 7 \\
\hline $\begin{array}{l}\text { Jenis } \\
\text { Tanah }\end{array}$ & $\begin{array}{l}0.11111 \\
11\end{array}$ & $\begin{array}{l}0.142 \\
857\end{array}$ & 0.2 & 1 & 0.2 \\
\hline $\begin{array}{l}\text { Ketinggian } \\
\text { Lokasi }\end{array}$ & $\begin{array}{l}0.11111 \\
1\end{array}$ & $\begin{array}{l}0.111 \\
111\end{array}$ & 0.143 & 5 & 1 \\
\hline
\end{tabular}

4.2 Perhitungan Bobot prioritas Kriteria Pertama-tama menyusun hirarki dimana diawali dengan tujuan, kriteria dan alternatif-alternatif lokasi pada tingkat paling bawah. Selanjutnya menetapkan perbandingan berpasangan antara kriteriakriteria dalam bentuk matrik. Nilai diagonal matrik untuk perbandingan suatu elemen dengan elemen itu sendiri diisi dengan bilangan (1) sedangkan isi nilai perbandingan antara (1) sampai dengan (9) kebalikannya, kemudian dijumlahkan perkolom. Data matrik tersebut seperti terlihat pada tabel bobot prioritas kriteria

Menjumlahkan masing-masing baris dari setiap kolom :

Kualitas Air (K1): Baris $1+$ Baris $2+$ Baris $3+$ Baris $4+$ Baris 5....... $\{1\}$ 
Total $=$ Hasil dari Penjumlahan Diatas Contoh untuk mencari nilai total kolom pertama Total $=1+0.333333+0.2+$ $0.1111111+0.111111=1.76$

Tabel 4.2 Tabel Bobot Prioritas Kriteria

\begin{tabular}{|l|l|l|l|l|l|}
\hline Kriteria & $\begin{array}{l}\text { Kualitas } \\
\text { Air }\end{array}$ & $\begin{array}{l}\text { Kadar } \\
\text { Air }\end{array}$ & $\begin{array}{l}\text { Suhu } \\
\text { Air }\end{array}$ & $\begin{array}{l}\text { Jenis } \\
\text { Tana } \\
\text { h }\end{array}$ & $\begin{array}{l}\text { Ketinggi } \\
\text { an } \\
\text { Lokasi } \\
\text { dan air } \\
\text { laut }\end{array}$ \\
\hline $\begin{array}{l}\text { Kualitas } \\
\text { Air }\end{array}$ & 1 & 3 & 5 & 9 & 9 \\
\hline $\begin{array}{l}\text { Kadar } \\
\text { Air }\end{array}$ & 0.33333 & 1 & 5 & 7 & 9 \\
\hline Suhu Air & 0.2 & 0.2 & 1 & 5 & 7 \\
\hline $\begin{array}{l}\text { Jenis } \\
\text { Tanah }\end{array}$ & $\begin{array}{l}0.11111 \\
11\end{array}$ & $\begin{array}{l}0.1428 \\
57\end{array}$ & 0.2 & 1 & 0.2 \\
\hline $\begin{array}{l}\text { Ketinggi } \\
\text { an } \\
\text { Lokasi }\end{array}$ & $\begin{array}{l}0.11111 \\
1\end{array}$ & 0.1111 & 0.1438 & 5 & 1 \\
\hline Total & 1.76 & 4.45 & 11.34 & 27 & 26.2 \\
\hline
\end{tabular}

\subsection{Normalisasi Matriks dan Bobot Prioritas}

Setelah terbentuk matrik perbandingan maka dilihat bobot prioritas untuk perbandingan kriteria. Dengan cara membagi isi matriks perbandingan dengan jumlah kolom yang bersesuaian, kemudian menjumlahkan perbaris setelah itu hasil penjumlahan dibagi dengan banyaknya kriteria sehingga ditemukan bobot prioritas seperti terlihat pada berikut.

Rumus menormalisasi matriks : Membagi setiap elemen matriks dengan baris total

Contoh cell Kualitas air-Kualitas air $=\frac{1}{2.41}$ $=0.413$

Rumus Mencari Bobot Prioritas : Mencari rata-rata dari setiap baris hasil normalisai.

Bobot Prioritas $=\frac{\sum \text { Hasil Normalisasi }}{N}\{2\}$

Contoh nilai bobot prioritas kolom pertama $=\frac{0.57+0.674+0.441 \pm 0.333+0.344}{5}=0.472$

\subsection{Konsistensi Matriks}

bobot prioritas kriteria A, isi kolom B matriks perbandingan dengan bobot prioritas kriteria B dan seterusnya. Kemudian dijumlahkan setiap barisnya dan dibagi penjumlahan baris dengan bobot prioritas bersesuaian seperti terlihat pada tabel berikut

CM (Consistency Measure) didapat dari mengalikan matriks pada tabel perbandingan kriteria dengan bobot prioritas masing-masing baris

$\mathrm{CM}=\frac{\Sigma(M \times B P)}{B P}$

Dimana, $\mathrm{M}=$ Nilai matriks dari setiap cell di tabel perbandingan kriteria $\mathrm{BP}=$ Bobot Kriteri, Contoh untuk baris pertama

$\mathrm{CM}=$

$\frac{(1 \times 0.472)+(3 \times 0.292)+(5 \times 0.14)+(9 \times 0.032)+(9 \times 0.065)}{0.472}$ $=6.17$

4.5 Ratio Index Berdasarkan Ordo Matriks Tabel 4.3 Tabel Ratio Index Berdasarkan Ordo Matriks

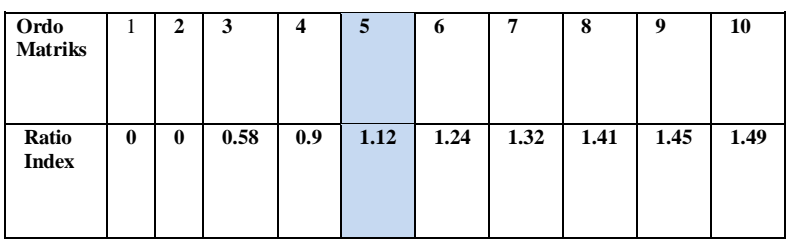

$\mathrm{n}$ adalah jumlah kriteria (ukuran matriks) $=$ 5 ,

Ratio Index 5 Kritera: 1.12

Karena matriks terdiri dari 5 kriteria maka otomatis RI = 1.12.

Hasil

$\lambda$ maks (lamda maks) $: 5.9326$

Lambda Max itu adalah rata-rata dari CM (Consistency Measure) = $6.17+6.7+6.46+5.28+5.05$

5 5.9326

Consistency Index: 0.10145

$\mathrm{CI}=$ $\frac{\lambda \operatorname{Max}-n}{n-1}$

$\mathrm{CI}=\frac{5.9326-5}{5-1}=0.23315$

Consistency Ratio: $\quad 0.09058$ (Konsisten)Dari CI dan RI, kita bisa menghitung Consistency Ratio dengan cari $\frac{C I}{R I}=\frac{0.23315}{1.12}=0.20817$

$\begin{array}{lllll}\text { Untuk nilai } & \mathrm{CR} & 0 & - & 0.1\end{array}$ dianggap konsisten lebih dari itu tidak 
konsisten. Sehingga perbandingan yang diberikan untuk kriteria sudah konsisten.

\subsection{Perangkingan}

Untuk mencari nilai total (Rank) dengan mengalikan bobot prioritas kriteria dengan setiap baris matriks bobot prioritas alternatif.

$$
\text { Ranking }=\Sigma(B P K * B P A)
$$

Dimana, BPK = Bobot Prioritas kriteria $\mathrm{BPA}=$ Bobot Prioritas Alternatif

Data jenis bibit ikan yang digunakan sebanyak 5 jenis yaitu Ikan Patin, Ikan Mas, Ikan Gurame, Ikan Nila dan Ikan Gabus dengan Jumlah sample yang digunakan sebanyak 50 bibit.

Tabel 4.6 Tabel Hasil Perangkingan

\begin{tabular}{|c|l|l|l|}
\hline $\begin{array}{c}\text { Ranki } \\
\text { ng }\end{array}$ & $\begin{array}{c}\text { Nama } \\
\text { Alternatif }\end{array}$ & $\begin{array}{l}\text { Altern } \\
\text { atif }\end{array}$ & \multicolumn{1}{|c|}{ Hasil } \\
\hline 1 & $\begin{array}{l}\text { Alternatif } \\
5\end{array}$ & $\begin{array}{l}\text { Ikan } \\
\text { Patin }\end{array}$ & $\begin{array}{l}0.247329 \\
1799734 \\
1\end{array}$ \\
\hline 2 & $\begin{array}{l}\text { Alternatif } \\
4\end{array}$ & $\begin{array}{l}\text { Ikan } \\
\text { Mas }\end{array}$ & $\begin{array}{l}0.217815 \\
217572\end{array}$ \\
\hline 3 & $\begin{array}{l}\text { Alternatif } \\
3\end{array}$ & $\begin{array}{l}\text { Ikan } \\
\text { Gura } \\
\text { me }\end{array}$ & $\begin{array}{l}0.185560 \\
5387360 \\
7\end{array}$ \\
\hline 4 & $\begin{array}{l}\text { Alternatif } \\
2\end{array}$ & $\begin{array}{l}\text { Ikan } \\
\text { Nila }\end{array}$ & $\begin{array}{l}0.181886 \\
8105945 \\
6\end{array}$ \\
\hline 5 & $\begin{array}{l}\text { Alternatif } \\
1\end{array}$ & $\begin{array}{l}\text { Ikan } \\
\text { Gabus }\end{array}$ & $\begin{array}{l}0.167408 \\
2531239 \\
6\end{array}$ \\
\hline
\end{tabular}

\subsection{Tampilan Awal sistem}

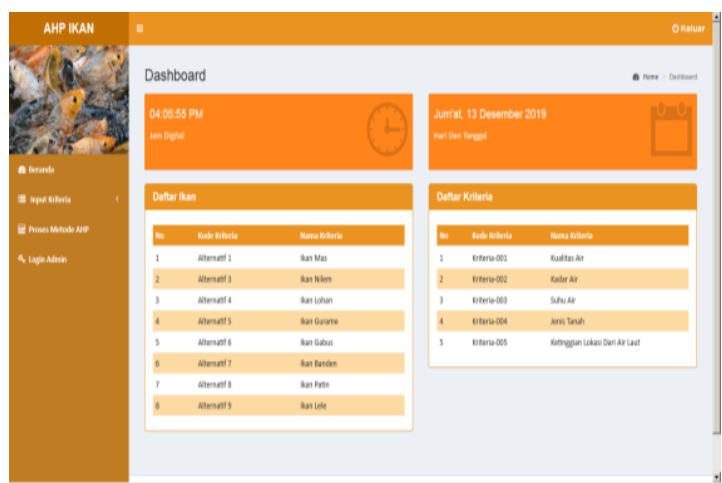

Gambar 4.1 Tampilan Awal Sistem

Gambar diatas merupakan halaman menu utama yang di gunakan oleh user. Dimana pada menu utama ini akan menampilkan menu - menu seperti menu nilai kriteria yang terdiri nilai bobot kriteria dan nilai bobot alternatif serta terdapat menu proses metode AHP dan menu login admin.

\subsection{Tampilan Proses AHP}

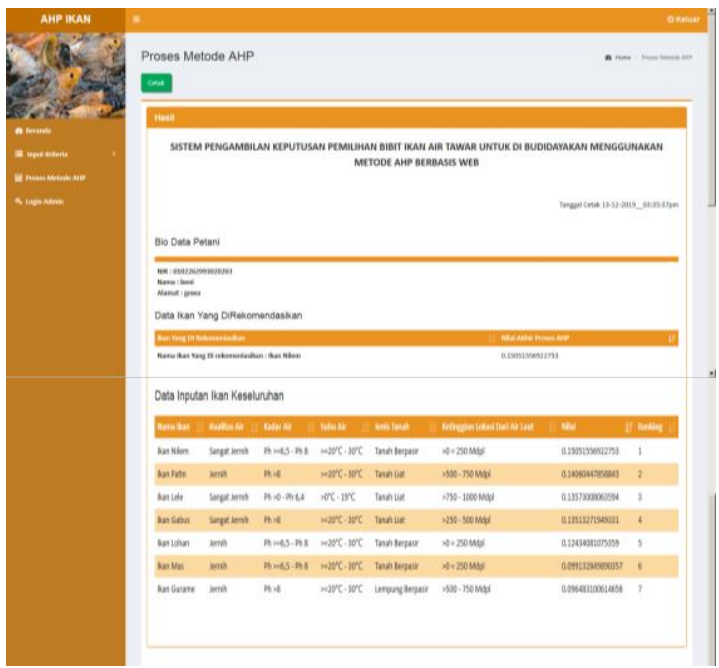

Gambar 4.2 Tampilan Proses AHP

Gambar diatas merupakan halaman menu untuk Melihat proses AHP yang di gunakan oleh user. Dimana pada menu utama ini akan menampilkan hasil proses AHP seperti nama ikan,kualitas Air,Kadar Air,Suhu Air,Jenis Tanah, ketinggian lokasi dari laut dan nilai. 


\section{SIMPULAN DAN SARAN}

5.1 Simpulan

Sistem ini mampu memberikan rekomendasi kepada petani untuk pemilihan bibit ikan air tawar yang akan dibudidayakan.

\subsection{Saran}

Diharapkan sistem yang dirancang selanjutnya dapat ditambahkan metode dan kriteria untuk dibandingkan

\section{DAFTAR PUSTAKA}

Jumarlis, M. (2020). Implementasi Algoritma Double Exponential Smoothing Pada Sistem Peramalan Persediaan Barang. INSTEK (Informatika Sains Dan Teknologi), 5, 251-260.

Kosasi, S., Kuway, S. M., Ayu, I. D., \& Yuliani, E. (2015). Perancangan Sistem Perangkat Lunak Penunjang Keputusan Memilih Bibit Ikan Air Tawar ISBN : 979-26-0280-1 ISBN : 979-26-0280-1. Seminar Nasional Teknologi Informasi Dan Komunikasi Terapan, 23-28.

Lumentut, H. B., \& Hartati, S. (2015). Sistem Pendukung Keputusan untuk Memilih Budidaya Ikan Air Tawar Menggunakan AF-TOPSIS. IJCCS (Indonesian Journal of Computing and Cybernetics Systems), 9(2), 197. https://doi.org/10.22146/ijccs.7548

Nugroho, R. A., Pambudi, L. T., Chilmawati, D., \& Condro, H. (2012). Aplikasi Teknologi Aquaponic Pada Budidaya Ikan Air Tawar Untuk Optimalisasi Kapasitas Produksi. SAINTEK PERIKANAN : Indonesian Journal of Fisheries Science and Technology, 8(1), 46-51. https://doi.org/10.14710/ijfst.8.1.4651

Rosiska, E. (2018). Penerapan Metode Analitycal Hierarchy Process (AHP) dalam Menentukan Mitra Usaha Berprestasi. Jurnal RESTI (Rekayasa Sistem Dan Teknologi Informasi), 2(2), 479-485. https://doi.org/10.29207/resti.v2i2.41 9

Wargasasmita, S., Biologi, J., Pusat, D., Biodiversitas, S., \& Fmipa-Ui, K. (2002). Ikan Air Tawar Endemik Sumatra Yang Terancam Punah (The freshwater fishes of endemic of Sumatra that threatened species). Jumal Iktiologi Indonesia, 2(2), 4-49. 